ISSN 1112-9867

Available online at

http://www.jfas.info

\title{
THE SUPPLEMENTARY IRRIGATION EFFECTS ON DROUGHT TOLERANCE AND ORNAMENTAL CHARACTERISTICS OF SAFFLOWER VARIETIES
}

\author{
M. E. Torbaghan ${ }^{1, *}$, H. Nemati ${ }^{2}$ and A. Tehranifar ${ }^{2}$ \\ ${ }^{1}$ Agricultural Research and Education Organization \\ ${ }^{2}$ Academic member of Ferdowsi university of Mashhad
}

Published online: 13 June 2016

\begin{abstract}
Supplementary irrigation is a high-performance operation for increasing crop production and income of farmers in dryland conditions. In order to study the effect of supplementary irrigation on drought tolerance and ornamental characteristics of safflower genotypes an experiment was conducted in 2013-14 at North Khorasan Dryland Agricultural Research Station. The experimental design was split plot based on RCBD. Factors were included five levels of irrigation, i.e., no irrigation, irrigation at rosette stage, flowering stage, seed filling and irrigation in flowering + seed filling as the main factors, and sub factors were varieties in three levels included Feraman, Sina and Syrian. The effect of supplementary irrigation on harvest index, seed/main head, seed/sub head, thousand kernel weight and seed yield was significant. The effect of supplementary irrigation on traits: RGR, CGR, hollow seeds, number of flowers and flower size was not significant. The highest yield and harvest index were obtained with irrigation at flowering stage in "Feraman". Since the "Feraman" variety has shiny red flowers and spineless leaves, is a good plant for flower trade.
\end{abstract}

Keywords: carthamus tinctorius; flower color; optimum irrigation; spineless leaf.

Author Correspondence, e-mail: tem3431@gmail.com

doi: $\underline{\text { http://dx.doi.org/10.4314/jfas.8vi2s.79 }}$ 


\section{INTRODUCTION}

Increasing consumption of vegetable oil and spend of costs equal 800 million dollars per year for a supply of vegetable oil, need to natural dye for having healthy foods and need to ornamental flowers, are important factors that shows necessity of extension of safflower research programs. Safflower (Carthamus tinctorius L.) is an annual plant that is adapted to hot and dry environments ( $\mathrm{Li}$ and Mundel 1996) with having vertical root type that can penetrate to soils a depth of two meter (Bagheri and Sam-Daliri, 2011). Supplementary irrigation in order to improve and stabilize production, small amounts of water are add to crops which are essentially rainfed, during periods which rain cannot provide sufficient moisture for normal development of plants (Oweis, 1997). Researchers observed that under water deficit conditions, supplementary irrigation during reproductive phases had a significant effect on seed yield (Kar et al, 2007). Damage caused by water shortage, reduced production due to delays of plant establishment, the plants prone to pests and diseases attack, changes in the plant biochemical and physiological processes and decrease crop quality. Scientists showed the harvest index in safflower did not significantly changes in five irrigation regimes, but kernel yield declined sharply when drought was severe (Lovely et al, 2007). Traditionally safflower was grown for its flower, used in coloring and flavoring food, making dyes, and in medicine. In the last 30 years, however, its production as an oilseed crop has received a great deal of attention. Most genotypes have many sharp spines on the leaves and bracts. Florets at the bloom stage display hues of yellow, orange, red, and rarely white coloration, that change to other colors at the wilted stage ( $\mathrm{Li}$ and Mundel, 1996). Flower color is generally considered neutral for seed yield and oil production, but when safflower is grown for the florets, flower color is important. The most important characteristics in safflower that determine its ornamental value are a combination of flower color and few to no spines on the flowers and bracts. Iran is one of the centers of safflower culture in the old world (Knowles 1969) and different local populations of this crop are found throughout the country (Zeinali 1999). Bradley (1999) observed that among all evaluated genotypes, Iranian accessions with orange or yellow flowers showed promise for ornamental uses as fresh-cut and dried flowers. Safflower importance is increasing as a consequence of higher demand for dried flowers in the last two decades of century. Two decades ago, safflower was newly presented in professional articles in horticultural periodicals (Hegele, 1985, Hartrath, 1986). In 1990, safflower was placed at 46th position among the cut-flowers in Holland auctions already, with annual sales around 3,122,000 stems, $(1,419,000 €$, approximately). Ten years later it ranked 
39th, but annual sales trebled to 5,321,000 €. Nevertheless, surprising is not only the amount of harvested flowering stems $(47,021,000$ in 1999), but the fact that safflower walked over more popular annual cut-flowers, such as snapdragons, asters, celosias, gomphrenas, or marigolds at that time. Among the varieties, orange-flowered Zanzibar with 14429350 flowering stems substitute nearly 70 percent of total safflower annual sales, followed by Summer sun (681 100), Orange Grenade (650165), and Kinko (453080 flowering stems). Supplementary irrigation and its positive role in increasing the performance of rainfed lands has long been known (seekers and Pryor, 1988) conducted several studies on the impact of irrigation and the results showed good performance in such a situation (Avztrk et al. 2008). The objective of this study was investigation of the effect of supplementary irrigation on yield, yield components and ornamental traits of three safflower varieties.

\section{MATERIAL AND METHODS}

This study carried out in 2013-14 at dryland agricultural research station of North Khorasan using split plot experiment based on RCBD with four replications.

The experimental factors were: I) Irrigation as main plot with five levels contains $\mathrm{I}_{1}$ : without irrigation, $\mathrm{I}_{2}$ : one time irrigation in rosette stage, $\mathrm{I}_{3}$ : one time irrigation in flowering stage, $\mathrm{I}_{4}$ : one time irrigation in seed filling, $\mathrm{I}_{5}$ : two times irrigation in flowering and seed filling stages and V) Variety as sub plot with three levels contains $\mathrm{V}_{1}$ : Feraman, $\mathrm{V}_{2}$ : Sina and $\mathrm{V}_{3}$ : Syrian. The farm of the experiment in the last year was fallow. In order to preparing the seed bed, the land plowed, then twice disk and finally leveler were used.

The experiment was planted in the late October in the field. Each variety was sown in plots of 6 rows, 5-m long, with spacing of $25-\mathrm{cm}$ between rows. Irrigation was applied with counter in desired stages. Amount of irrigation was 640 liters for each plot. Data were analyzed using SAS software. Mean comparison was done using Duncan's multiple range tests.

Table 1. The results of soil analysis of North Khorasan Dryland Agricultural Research Station at a depth of 0 to $30 \mathrm{~cm}$ before planting

\begin{tabular}{llll}
\hline Characteristics & Results & Characteristics & Results \\
\hline Saturate percentage (\% ) & 40.2 & Absorbable phosphorus (ppm) & 8.8 \\
Electric conductivity ( ds/m ) & 0.4 & Absorbable potassium (ppm) & 264 \\
PH & 8.1 & Sand (\%) & 36 \\
T.N.T. (\%) & 2018 & Silt $(\%)$ & 43.6
\end{tabular}


Organic carbon (\%)

0.33

Clay $(\%)$

20.4

Total nitrogen (\%)

0.049

Soil texture

Clay loam

Table 2. Meteorological Statistics of North Khorasan dryland agricultural research station during safflower growth

\begin{tabular}{|c|c|c|c|c|c|c|c|c|c|}
\hline Month & $\begin{array}{l}\text { Rainf } \\
\text { all } \\
(\mathrm{mm})\end{array}$ & $\begin{array}{l}\text { Absolut } \\
\mathrm{e} \\
\text { minimu } \\
\mathrm{m} \\
\text { tempera } \\
\text { ture }\end{array}$ & $\begin{array}{l}\text { Absolut } \\
\text { e } \\
\text { maxim } \\
\text { um } \\
\text { tempera } \\
\text { ture }\end{array}$ & $\begin{array}{l}\text { Averag } \\
\mathrm{e} \\
\text { minimu } \\
\mathrm{m} \text { of } \\
\text { absolut } \\
\mathrm{e} \\
\text { tempera } \\
\text { ture }\end{array}$ & $\begin{array}{l}\text { Averag } \\
\text { e } \\
\text { maxim } \\
\text { um of } \\
\text { absolut } \\
\text { e } \\
\text { tempera } \\
\text { ture }\end{array}$ & $\begin{array}{l}\text { Average } \\
\text { temperat } \\
\text { ure }\end{array}$ & $\begin{array}{l}\text { Relati } \\
\text { ve } \\
\text { Humi } \\
\text { dity } \\
(\%)\end{array}$ & $\begin{array}{l}\text { The } \\
\text { num } \\
\text { ber } \\
\text { of } \\
\text { days } \\
\text { belo } \\
\text { w } \\
\text { zero }\end{array}$ & $\begin{array}{l}\text { Evaporati } \\
\text { on } \\
(\mathrm{mm})\end{array}$ \\
\hline $\begin{array}{l}\text { Octobe } \\
\mathrm{r}\end{array}$ & 1 & 7 & 30.8 & 9.9 & 24.7 & 17.3 & 45.8 & 0 & 75.5 \\
\hline $\begin{array}{l}\text { Nove } \\
\text { mber }\end{array}$ & 6.8 & -8 & 22.8 & 0.4 & 13.4 & 6.9 & 59.6 & 14 & 35.4 \\
\hline $\begin{array}{l}\text { Decem } \\
\text { ber }\end{array}$ & 6.6 & -12.4 & 19.4 & -0.2 & 10.4 & 5.1 & 66.9 & 10 & 0 \\
\hline $\begin{array}{l}\text { Januar } \\
\text { y }\end{array}$ & 6.3 & -13 & 17 & -4.9 & 6.4 & 0.7 & 72.2 & 26 & 0 \\
\hline $\begin{array}{l}\text { Februa } \\
\text { ry }\end{array}$ & 41.4 & -7 & 16.4 & -0.7 & 9.5 & 4.4 & 69.8 & 18 & 0 \\
\hline March & 37.6 & -4 & 27.6 & 2.1 & 14.3 & 8.2 & 58.7 & 7 & 0 \\
\hline April & 70.8 & -2.6 & 23.2 & 3.3 & 15.7 & 9.5 & 63.4 & 2 & 39.8 \\
\hline May & 20.6 & 2.2 & 28 & 8.3 & 21.7 & 15 & 61.8 & 0 & 70.6 \\
\hline June & 32 & 6.4 & 33 & 12.3 & 28.5 & 20.4 & 46 & 0 & 102.9 \\
\hline July & 7.5 & 15.4 & 37.4 & 17.8 & 33.1 & 25.4 & 40.3 & 0 & 70.9 \\
\hline August & 5 & 11.4 & 38.2 & 16.3 & 33.8 & 25 & 32.5 & 0 & 166.1 \\
\hline $\begin{array}{l}\text { Septe } \\
\text { mber }\end{array}$ & 0 & 11.4 & 37 & 15.7 & 32.9 & 24.3 & 30.7 & 0 & 153 \\
\hline
\end{tabular}




\section{RESULT AND DISCUSSION}

Since the beginning of precipitation and cold season in the cold dryland conditions is at the same time, Safflower do not have time to reach rosette stage and become cold resistant. Therefore, safflower planted in the fall must have a good tolerance to cold in the early growth season. In some reports, have mentioned that "Sina" variety had good resistance against the cold (Eskandari and Eskandari, 2009).

The effect of supplementary irrigation on seed yield was significant (table 3). The highest yield was belonging to $\mathrm{I}_{3}$, i.e. irrigation in flowering stage (table 4). Irrigation in flowering stage was effected on reproductive organs resulted in more yield production. Patel, (1993) reported that apply of drought stress at the beginning of flowering is the most important factor for yield reduction.

Table 3. Analysis of variance for safflower trial

\begin{tabular}{|c|c|c|c|c|c|c|c|c|c|}
\hline \multicolumn{2}{|l|}{ S.O.V. } & $\mathrm{df}$ & Dry weight & $\begin{array}{l}\text { Seed/Po } \\
\text { d }\end{array}$ & CGR & $\begin{array}{l}\text { Seed } \\
\text { yield }\end{array}$ & $\begin{array}{l}\text { Biomas } \\
\mathrm{s}\end{array}$ & $\begin{array}{l}\text { TKW } \\
\text { (gr) }\end{array}$ & $\begin{array}{l}\text { Harves } \\
\text { t Index }\end{array}$ \\
\hline Replication & & 3 & $42848.44^{*}$ & $191.10^{* * *}$ & $5.95^{\mathrm{ns}}$ & $\begin{array}{l}22055.31 \\
*\end{array}$ & $0.48^{*}$ & $51.99^{\mathrm{ns}}$ & $1.35^{\mathrm{ns}}$ \\
\hline \multicolumn{10}{|c|}{ Supplementar } \\
\hline $\mathrm{y}$ irrigation & & 4 & $2845.03^{\mathrm{ns}}$ & $689.50^{* *}$ & $11.47^{\mathrm{n}}$ & $\begin{array}{l}28205.12 \\
*\end{array}$ & $0.23^{\mathrm{ns}}$ & $54.10^{*}$ & $\begin{array}{l}152.84 \\
*\end{array}$ \\
\hline Error A & & $\begin{array}{l}1 \\
2\end{array}$ & 129.60 & 3.03 & 0.36 & 134.57 & 0.07 & 0.13 & 0.55 \\
\hline Variety & & 2 & $\begin{array}{l}106472.49^{*} \\
*\end{array}$ & $14.60 \mathrm{~ns}$ & $\begin{array}{l}14.53^{\mathrm{n}} \\
\mathrm{s}\end{array}$ & $9688.39^{\mathrm{ns}}$ & $0.03^{\mathrm{ns}}$ & $\begin{array}{l}275.72^{*} \\
*\end{array}$ & $77.52^{* *}$ \\
\hline $\begin{array}{l}\text { Irrigation } \\
\text { Variety }\end{array}$ & $x$ & 8 & $31520.04^{*}$ & $67.35^{*}$ & $7.55^{\mathrm{ns}}$ & $\begin{array}{l}16652.61 \\
*\end{array}$ & $0.10^{\mathrm{ns}}$ & $6.45^{\mathrm{ns}}$ & $27.09^{\mathrm{ns}}$ \\
\hline Error B & & $\begin{array}{l}3 \\
0\end{array}$ & 407.93 & 0.61 & 0.23 & 70.66 & 0.06 & 0.88 & 1.00 \\
\hline C.V. (\%) & & & 18.18 & 16.49 & 29.94 & 21.52 & 15.22 & 11.21 & 16.91 \\
\hline
\end{tabular}


Generally, in the plants, critical stage for water requirement is flowering stage (Omidi, 1999). Results of research in several countries showed that the yield increased 15-200 percent in supplemental irrigation compare to dryland conditions (Perriee and Salkini, 1991). When the water is limited, using at least, one time irrigation when it is necessary, can increase the yield and water used efficiency, significantly (Oweis, 1997). It seems that the safflower plant in this study with increasing seed per pod and thousand kernel weights compensated decreasing of pods per plant.

The effect of variety on yield was non-significant (Table 3). Variety "Feraman" had the highest seed yield (490 Kg/ha) and the lowest seed yield belonged to "Syrian" (451 Kg/ha). Feraman due to high adaptability with cold dryland conditions could produce the highest yield. This variety with increasing vegetative growth and developing biological yield and having the highest biomass could use from environmental conditions, suitably. The table 4 showed "Feraman" had the highest crop growth ratio, dry weight, biomass and harvest index that verify above results.

Supplementary irrigation and variety interaction was significant on yield (Table 5). The highest seed yield was belong to $I_{3}$ treatment in Syrian $(612 \mathrm{Kg} / \mathrm{ha})$ and the lowest seed yield was belong to $I_{1}$ treatment in Sina equal to $349 \mathrm{Kg} / \mathrm{ha}$ (Table 5). It seems that Syrian had the highest positive reaction to supplementary irrigation at flowering stage. Irrigation at flowering stage in this variety was useful for reproductive phase of plant and with increasing seeds per pod and thousand kernel weight, that are the most important components effective on yield could reached to maximum yield. Also, Irrigation at flowering stage could cause a large increase in the biological yield in "Feraman".

\section{EFFECT OF DIFFERENT PHONOLOGICAL STAGES OF SUPPLEMENTARY IRRIGATION AND VARIETY ON SOME SAFFLOWER TRAITS}

\begin{tabular}{|c|c|c|c|c|c|c|c|}
\hline Factor & Seed/Pod & $\begin{array}{l}\text { Seed } \\
\text { yield } \\
(\mathrm{kg} / \mathrm{h})\end{array}$ & $\begin{array}{l}\text { CGR } \\
\left(g \cdot m^{-}\right. \\
{ }^{2} \text {.day } \\
\left.{ }^{1}\right)\end{array}$ & $\begin{array}{l}\text { Harvest } \\
\text { Index } \\
(\%)\end{array}$ & $\begin{array}{l}\text { TKW } \\
\text { (gr) }\end{array}$ & $\begin{array}{l}\text { Biomass } \\
(\mathrm{kg} / \mathrm{m} 2)\end{array}$ & $\begin{array}{l}\text { Dry } \\
\text { weight } \\
\text { (gr) }\end{array}$ \\
\hline $\begin{array}{ll}\text { Supplementary } & \mathrm{I}_{1} \\
\text { irrigation } & \end{array}$ & $21.95 \mathrm{~b}$ & $392.46 \mathrm{~b}$ & $6.23 \mathrm{a}$ & $18.95 \mathrm{~b}$ & $\begin{array}{l}38.04 \\
b\end{array}$ & $1.53 \mathrm{~b}$ & $\begin{array}{l}557.80 \\
\text { a }\end{array}$ \\
\hline (I) & $25.75 b$ & 463.71 & $6.73 \mathrm{a}$ & $19.35 \mathrm{~b}$ & 40.72 & $1.88 \mathrm{a}$ & 595.31 \\
\hline
\end{tabular}




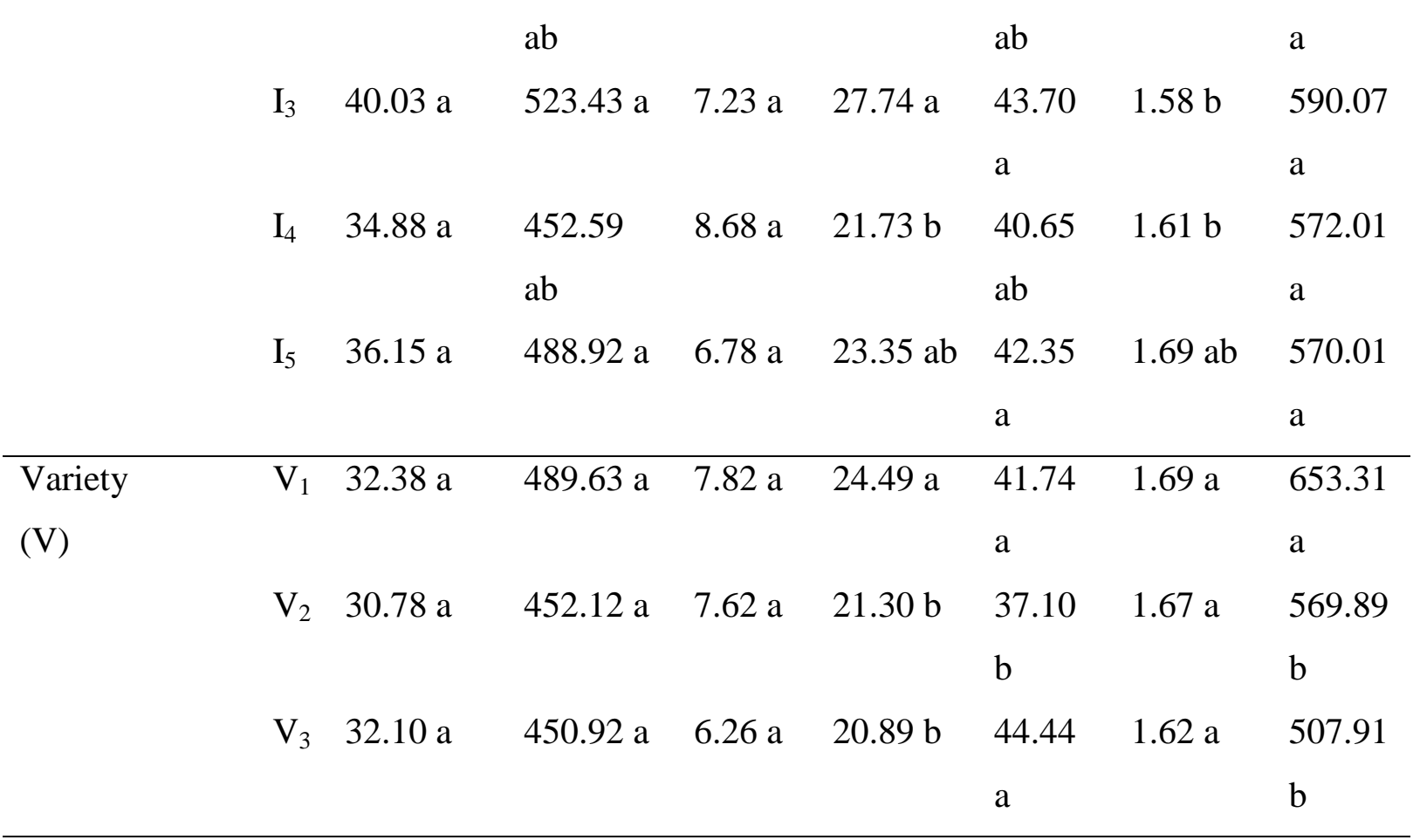

$\mathrm{I}_{1}$ : No irrigation, $\mathrm{I}_{2}$ : Irrigation in rosette stage, $\mathrm{I}_{3}$ : Irrigation in flowering stage, $\mathrm{I}_{4}$ : Irrigation in seed filling stage, $\mathrm{I}_{5}$ : Irrigation in flowering and seed filling stages., $\mathrm{V}_{1}$ : Feraman, $\mathrm{V}_{2}$ : Sina, $\mathrm{V}_{3}$ : Syrian.

$\dagger$ Different letters in each column is indicated significant difference at 5\% level

Effect of supplementary irrigation on harvest index was significant at 5\% probability level (Table 3). The highest harvest index was belonging to the treatments $I_{3}$ and $I_{5}$ with values of 27.74 and 23.35, respectively (Table 4). The lowest harvest index (18.95 percent) was allocated to treatment $\mathrm{I}_{1}$ (Table 4). Harvest index is a portion of biological yield that form economic production, which is also called the coefficient of efficiency. In treatment $\mathrm{I}_{3}$ that had the highest harvest index, it seems that irrigation in flowering stage via effect on economic yield compare with biological yield could increased harvest index, because this treatment had the highest yield but did not have the highest biomass and treatment $\mathrm{I}_{2}$ had the highest biomass. So, irrigation in treatment $\mathrm{I}_{3}$ was useful for reproductive growth of plant i.e. increasing seeds per pod and thousand kernel weight. In some plants, increasing seed yield is due to increasing harvest coefficient. In other hand, plant does not produce additional dry matter, but main part of dry matter allocated to seed economic yield (Sarmadnia and koocheki, 1993). 


\section{EFFECT OF DIFFERENT PHONOLOGICAL STAGES OF SUPPLEMENTARY IRRIGATION AND VARIETY ON SOME SAFFLOWER TRAITS}

\begin{tabular}{|c|c|c|c|c|c|c|}
\hline \multirow[b]{2}{*}{ Irrigation } & \multirow[b]{2}{*}{ variety } & \multicolumn{5}{|l|}{ Means } \\
\hline & & $\begin{array}{l}\text { No. of } \\
\text { Flowers }\end{array}$ & $\begin{array}{l}\text { Seed Yield } \\
(\mathrm{kg} / \mathrm{h})\end{array}$ & $\begin{array}{l}\text { Thousand } \\
\text { Kernel } \\
\text { Weight } \\
\text { (gr) }\end{array}$ & $\begin{array}{l}\text { Dry Weight } \\
\text { (gr) }\end{array}$ & $\begin{array}{l}\text { Seed per } \\
\text { Main Pod }\end{array}$ \\
\hline $\mathrm{I}_{1}$ & $\mathrm{~V}_{1}$ & $5.35 \mathrm{a}$ & $424.0 \mathrm{bcd}$ & 40.9 abcd & $605.5 \mathrm{bcd}$ & $17.2 \mathrm{~b}$ \\
\hline $\mathrm{I}_{1}$ & $\mathrm{~V}_{2}$ & $5.75 \mathrm{a}$ & $349.4 \mathrm{~d}$ & $32.4 \mathrm{e}$ & $547.5 \mathrm{bcdef}$ & $21.4 \mathrm{ab}$ \\
\hline $\mathrm{I}_{1}$ & $\mathrm{~V}_{3}$ & $5.35 \mathrm{a}$ & $404.0 \mathrm{bcd}$ & $44.4 \mathrm{ab}$ & $431.5 \mathrm{f}$ & $23.8 \mathrm{ab}$ \\
\hline $\mathrm{I}_{2}$ & $\mathrm{~V}_{1}$ & $6.75 \mathrm{a}$ & $526.9 \mathrm{ab}$ & 38.6 bcde & 766.8 a & $18.4 \mathrm{~b}$ \\
\hline $\mathrm{I}_{2}$ & $\mathrm{~V}_{2}$ & $5.92 \mathrm{a}$ & $441.3 \mathrm{bcd}$ & 36.9 cde & $562.9 \mathrm{bcdef}$ & $17.4 \mathrm{~b}$ \\
\hline $\mathrm{I}_{2}$ & $\mathrm{~V}_{3}$ & $5.55 \mathrm{a}$ & $423.0 \mathrm{bcd}$ & $43.2 \mathrm{abc}$ & $456.2 \mathrm{ef}$ & $18.1 \mathrm{~b}$ \\
\hline $\mathrm{I}_{3}$ & $\mathrm{~V}_{1}$ & $5.65 \mathrm{a}$ & $461.4 \mathrm{bcd}$ & $44.8 \mathrm{ab}$ & $540.6 \mathrm{cdef}$ & $26.8 \mathrm{a}$ \\
\hline $\mathrm{I}_{3}$ & $\mathrm{~V}_{2}$ & $5.90 \mathrm{a}$ & $496.7 \mathrm{abc}$ & $40.3 \mathrm{abcd}$ & 596.0 bcde & $22.2 \mathrm{ab}$ \\
\hline $\mathrm{I}_{3}$ & $\mathrm{~V}_{3}$ & $5.25 \mathrm{a}$ & $612.2 \mathrm{a}$ & $46.1 \mathrm{a}$ & $536.6 \mathrm{cdef}$ & $24.5 \mathrm{ab}$ \\
\hline $\mathrm{I}_{4}$ & $\mathrm{~V}_{1}$ & $5.67 \mathrm{a}$ & $529.7 \mathrm{ab}$ & $42.0 \mathrm{abcd}$ & $669.3 \mathrm{abc}$ & $25.1 \mathrm{ab}$ \\
\hline $\mathrm{I}_{4}$ & $\mathrm{~V}_{2}$ & $6.20 \mathrm{a}$ & $469.2 \mathrm{bcd}$ & $35.9 \mathrm{de}$ & 470.0 def & $17.7 \mathrm{~b}$ \\
\hline $\mathrm{I}_{4}$ & $\mathrm{~V}_{3}$ & $5.40 \mathrm{a}$ & $358.9 \mathrm{~cd}$ & $44.1 \mathrm{abc}$ & 576.6 bcde & $21.1 \mathrm{ab}$ \\
\hline $\mathrm{I}_{5}$ & $\mathrm{~V}_{1}$ & $5.30 \mathrm{a}$ & $506.2 \mathrm{ab}$ & $42.5 \mathrm{abcd}$ & $684.2 \mathrm{ab}$ & $19.5 \mathrm{ab}$ \\
\hline $\mathrm{I}_{5}$ & $\mathrm{~V}_{2}$ & $6.00 \mathrm{a}$ & $504.1 \mathrm{ab}$ & $40.0 \mathrm{abcd}$ & $672.9 \mathrm{abc}$ & $23.4 \mathrm{ab}$ \\
\hline $\mathrm{I}_{5}$ & $\mathrm{~V}_{3}$ & $5.35 \mathrm{a}$ & $456.5 \mathrm{bcd}$ & $44.6 \mathrm{ab}$ & 538.4 cdef & $23.4 \mathrm{ab}$ \\
\hline
\end{tabular}

$\dagger$ Different letters in each column is indicated significant difference at 5\% level

\section{CORRELATION BETWEEN PLANT PARAMETERS}

It was found that among the indices, the number of seeds per main head and thousand seed weight had significant positive correlation with the yield equal to $0.59^{*}$ and $0.60^{*}$, respectively (Table 6). With respect to this fact that the effect of these two traits on yield, also were significant in analysis of variance and mean comparison tables, the number of seeds per main head and thousand seed weight were the most important characteristics in seed production, that correlation coefficients verified it. 
Results (Table 6) showed that harvest index had highly significant positive correlation with yield, too $\left(\mathrm{r}=0.83^{* *}\right)$. Correlation coefficients table showed that the total pods in plant had significant positive correlation with the number of sub branches $\left(\mathrm{r}=0.61^{* *}\right)$. Also, plant dry weight had significant positive correlation with CGR $\left(r=0.58^{*}\right)$. Cold tolerance of safflower genotypes is very important in cold dryland farming (Eskandari and Eskandari, 2009). Between stand and number of hollow seeds were a significant positive correlation $\left(\mathrm{r}=0.73^{* *}\right)$. It seems that when stand and plant establishment rises and a large number of plants grow together in one place the competition between the plants increased the number of seeds that are unfilled due to reduced food and water for the seeds of each plant.

In the table 6 can be seen that the total number of pods had very significant negative correlation with thousand kernel weight $\left(\mathrm{r}=-0.68^{* *}\right)$. It is clear that with increasing number of pods in the plant, thousand kernel weights will decrease. The result of the present study confirms earlier works reporting an inverse relationship of important seed yield and oil content components (Patil and Deshmukh, 1998; Ramachandram, 1983). In addition, a very significant positive correlation $\left(r=0.72^{* *}\right)$ observed between biomass and plant height. Since plant height represents the biomass, by increasing plant height the amount of biological yield (biomass) will increase, too.

Supplementary irrigation and varieties on phenological, morphological, physiological traits and yield components had different effects that these effects were significant in some of the traits.

The main result of this study was due to the low yield of safflower in cold and arid drylands and the effective role of supplementary irrigation to increase product performance and economic value of water supply in this area, supplementary irrigation management applying even at one time - in this study at flowering stage - can caused increasing equal to $131 \mathrm{Kg} / \mathrm{ha}$ compare with complete dryland farming, this means that once irrigation in flowering stage compare with dry land farming, $31 \%$ yield increasing is obtained. In addition, the "Feraman" variety has beautiful red flowers and spineless leaves and brackets, and it seems that is a good plant for flower trade, not only as a fresh-cut flower but also as a dried flower.

\section{REFERENCES}

[1] Eskandari Torbaghan, M. and Eskandari M. The effect of planting density on seed and oil yield of two varieties in Entezari planting (Dormant seeding) under dryland conditions. Iranian agricultural researches journal, 2009, 7(1). 
[2] Bradley, V., Guenthner R., Johnson R. and Hannan. Evaluation of Safflower germplasm for ornamental use. Perspectives on new crops and new uses, ASHS Press, Alexandria, VA, 1999.

[3] Patil, H. S and R. B. Deshmukh. Studies on genetic variability and interrelationship in safflower. J. Oilseeds Research, 1998, 15, 50-53.

[4] Perriee, E. R., and Salkini A.B. Supplemental irrigation in the Near East and North Africa. ICARDA, Syria, 1991.

[5] Ramachandram, M. Genetic analysis and character association of seed yield, oil content and their components in safflower (Carthamus tinctorius L.). Ph.D. Thesis, UAS, Bangalore, 1983.

[6] Uher J and Kobza F. Herbicide applications in the cultures of safflower (Carthamus tinctorius L.) to be used for flower production, 1997.

[7] Vringer K and Blok K. The energy requirement of cut flowers and consumer options to reduce it. Resources, Conservation and Recycling, 2000, 28: 3-28.

[8] Oweis, T. Supplemental irrigation: A highly efficient water-use practice. ICARDA, Aleppo. Syria, 1997.

\section{How to cite this article:}

Torbaghan M. E, Nemati $\mathrm{H}$ and Tehranifar A. The supplementary irrigation effects on drought tolerance and ornamental characteristics of safflower varieties. J. Fundam. Appl. Sci., 2016, 8(2S), 641-652. 
8. CORRELATION COEFFICIENTS BETWEEN SOME TRAITS IN DRYLAND CONDITIONS UNDER DIFFERENT IRRIGATIONS

\begin{tabular}{|c|c|c|c|c|c|c|c|c|c|c|c|c|c|c|c|c|c|}
\hline Traits & Stand & SSP & SMP & GY & HS & RGR & CGR & TKW & DSF & $\begin{array}{l}\text { DF } \\
90 \%\end{array}$ & DSE & DW & $\mathrm{PH}$ & SB & PP & $\mathrm{HI}$ & $\mathrm{BM}$ \\
\hline Stand & 1 & & & & & & & & & & & & & & & & \\
\hline SSP & $0.11^{\mathrm{ns}}$ & 1 & & & & & & & & & & & & & & & \\
\hline SMP & $0.06^{\mathrm{ns}}$ & $0.24^{\mathrm{ns}}$ & 1 & & & & & & & & & & & & & & \\
\hline GY & $0.10^{\mathrm{ns}}$ & $0.17^{\mathrm{ns}}$ & $0.59^{*}$ & 1 & & & & & & & & & & & & & \\
\hline HS & $0.73^{* *}$ & $0.17^{\mathrm{ns}}$ & $0.07^{\mathrm{ns}}$ & $0.27^{\mathrm{ns}}$ & 1 & & & & & & & & & & & & \\
\hline RGR & $0.43^{\mathrm{ns}}$ & $0.47^{\mathrm{ns}}$ & $0.18^{\mathrm{ns}}$ & $0.45^{\mathrm{ns}}$ & $0.27^{\mathrm{ns}}$ & 1 & & & & & & & & & & & \\
\hline CGR & $0.31^{\mathrm{ns}}$ & $0.46^{\mathrm{ns}}$ & $0.26^{\mathrm{ns}}$ & $0.17^{\mathrm{ns}}$ & $0.11^{\mathrm{ns}}$ & $0.63^{*}$ & 1 & & & & & & & & & & \\
\hline TKW & $0.27^{\mathrm{ns}}$ & $0.20^{\mathrm{ns}}$ & $0.49^{\mathrm{ns}}$ & $0.60^{*}$ & $0.03^{\mathrm{ns}}$ & $0.28^{\mathrm{ns}}$ & $0.37^{\mathrm{ns}}$ & 1 & & & & & & & & & \\
\hline DSF & $0.09^{\text {ns }}$ & $0.31^{\mathrm{ns}}$ & $0.41^{\mathrm{ns}}$ & $0.22^{\mathrm{ns}}$ & $0.07^{\mathrm{ns}}$ & $0.09^{\mathrm{ns}}$ & $0.45^{\mathrm{ns}}$ & $0.07^{\mathrm{ns}}$ & 1 & & & & & & & & \\
\hline DF90 & $0.17^{\mathrm{ns}}$ & $0.27^{\mathrm{ns}}$ & $0.33^{\mathrm{ns}}$ & $0.11^{\mathrm{ns}}$ & $0.25^{\mathrm{ns}}$ & $0.35^{\mathrm{ns}}$ & $0.32^{\mathrm{ns}}$ & $0.21^{\mathrm{ns}}$ & $0.16^{\mathrm{ns}}$ & 1 & & & & & & & \\
\hline \multicolumn{18}{|l|}{$\%$} \\
\hline DSE & $0.07^{\mathrm{ns}}$ & $0.10^{\mathrm{ns}}$ & $0.30^{\mathrm{ns}}$ & $0.20^{\mathrm{ns}}$ & $0.05^{\mathrm{ns}}$ & $0.09^{\mathrm{ns}}$ & $0.08^{\mathrm{ns}}$ & $0.22^{\mathrm{ns}}$ & $0.05^{\mathrm{ns}}$ & $0.72^{* *}$ & 1 & & & & & & \\
\hline DW & $0.08^{\mathrm{ns}}$ & $0.15^{\mathrm{ns}}$ & $0.03^{\mathrm{ns}}$ & $0.28^{\mathrm{ns}}$ & $0.06^{\mathrm{ns}}$ & $0.21^{\mathrm{ns}}$ & $0.58^{*}$ & $0.18^{\mathrm{ns}}$ & $0.37^{\mathrm{ns}}$ & $0.15^{\mathrm{ns}}$ & $0.19^{\mathrm{ns}}$ & 1 & & & & & \\
\hline $\mathrm{PH}$ & $0.02^{\mathrm{ns}}$ & $0.16^{\mathrm{ns}}$ & $0.47^{\mathrm{ns}}$ & $0.09^{\mathrm{ns}}$ & $0.19^{\mathrm{ns}}$ & $0.32^{\mathrm{ns}}$ & $0.12^{\mathrm{ns}}$ & $0.32^{\mathrm{ns}}$ & $0.01^{\mathrm{ns}}$ & $0.19^{\mathrm{ns}}$ & $0.04^{\mathrm{ns}}$ & $0.04^{\mathrm{ns}}$ & 1 & & & & \\
\hline SB & $0.26^{\mathrm{ns}}$ & $0.24^{\mathrm{ns}}$ & $0.04^{\mathrm{ns}}$ & $0.14^{\mathrm{ns}}$ & $0.40^{\mathrm{ns}}$ & $0.30^{\mathrm{ns}}$ & $0.18^{\mathrm{ns}}$ & $0.26^{\mathrm{ns}}$ & $0.13^{\mathrm{ns}}$ & $0.10^{\mathrm{ns}}$ & $0.14^{\mathrm{ns}}$ & $0.28^{\mathrm{ns}}$ & $0.36^{\mathrm{ns}}$ & 1 & & & \\
\hline
\end{tabular}




\begin{tabular}{|c|c|c|c|c|c|c|c|c|c|c|c|c|c|c|c|c|c|}
\hline $\mathrm{PP}$ & $0.17^{\mathrm{ns}}$ & $0.24^{\mathrm{ns}}$ & $0.01^{\mathrm{ns}}$ & $0.15^{\mathrm{ns}}$ & $0.12^{\mathrm{ns}}$ & $0.08^{\mathrm{ns}}$ & $0.26^{\mathrm{ns}}$ & - & $0.16^{\mathrm{ns}}$ & $0.10^{\mathrm{ns}}$ & $0.24^{\mathrm{ns}}$ & $0.39^{\mathrm{ns}}$ & $0.33^{\mathrm{ns}}$ & $0.61^{* * *}$ & 1 & & \\
\hline & & & & & & & & $0.68^{* *}$ & & & & & & & & & \\
\hline HI & $0.28^{\mathrm{ns}}$ & $0.08^{\mathrm{ns}}$ & $0.56^{\mathrm{ns}}$ & $0.83^{* *}$ & $0.31^{\mathrm{ns}}$ & $0.35^{\mathrm{ns}}$ & $0.13^{\mathrm{ns}}$ & $0.37^{\mathrm{ns}}$ & $0.24^{\mathrm{ns}}$ & $0.02^{\mathrm{ns}}$ & $0.18^{\mathrm{ns}}$ & $0.23^{\mathrm{ns}}$ & $0.49^{\mathrm{ns}}$ & $0.14^{\mathrm{ns}}$ & $0.09^{\mathrm{ns}}$ & 1 & \\
\hline BM & $0.22^{\mathrm{ns}}$ & $0.26^{\mathrm{ns}}$ & $0.44^{\mathrm{ns}}$ & $0.29^{\mathrm{ns}}$ & $0.02^{\mathrm{ns}}$ & $0.26^{\mathrm{ns}}$ & $0.16^{\mathrm{ns}}$ & $0.33^{\mathrm{ns}}$ & $0.06^{\mathrm{ns}}$ & $0.22^{\mathrm{ns}}$ & $0.18^{\mathrm{ns}}$ & $0.08^{\mathrm{ns}}$ & $0.72^{* *}$ & $0.51^{\mathrm{ns}}$ & $0.44^{\mathrm{ns}}$ & $0.28^{\mathrm{ns}}$ & 1 \\
\hline
\end{tabular}

SSP: Seed per sub pod, SMP: Seed per main pod, GY: Seed yield, HS: Number of hollow seeds, RGR: Relative growth ratio, CGR: Crop growth ratio, TKW: Thousand kernel weight, DSF: Days to start of flowering, DF90\%: Days to 90\% flowering, DSE: Days to stem elongation, DW: Plant dry weight, PH: Plant height, SB: Number of sub branch, PP: Pod per plant, HI: Harvest Index, BM: Biomass. 